\title{
Benarkah Relationship Quality Berdampak Terhadap Word Of Mouth?
}

\section{Is It True That Relationship Quality Impact Against Word Of Mouth?}

\author{
Dina Mayasari Soeswoyo ${ }^{1)}$, Ivan Christopher ${ }^{2)}$, \\ ${ }^{1)}$ Program Studi Diploma Empat Perhotelan, Sekolah Tinggi Pariwisata Bogor \\ ${ }^{2)}$ Program Studi Diploma Empat Perhotelan, Sekolah Tinggi Pariwisata Bogor
}

19 Mei 2019

\begin{abstract}
The high level of competition in the restaurant industry in the city of Bogor, makes industry players strive to develop the right marketing strategy to be able to maintain business continuity, increase revenue and number of guests. Not only maintaining the quality of food, drinks and services, but also need to think about other factors that can support their business. This study aims to describe the description of relationship quality and word of mouth in de'Leuit restaurant, which is one of Sundanese favorite restaurants in the city of Bogor. Besides that, it is also to analyze the impact or influence of the relationship quality on word of mouth. This research was conducted in June-July 2018, using a quantitative approach with linear regression analysis techniques. Data collection techniques used in this study through direct observation, questionnaires and literature studies. The results of the analysis indicate that the description of relationship quality and word of mouth in De'Leuit Bogor restaurants shows the average score included in the high or good category, and relationship quality in De 'Leuit Bogor restaurants have a positive impact on word of mouth with an impact of $20.1 \%$.
\end{abstract}

Keyword: relationship quality, word of mouth, positive recommendation, personal communication

\begin{abstract}
ABSTRAK
Tingginya tingkat persaingan usaha industri restoran di Kota Bogor, membuat para pelaku industri berupaya keras menyusun strategi pemasaran yang tepat untuk dapat menjaga kelangsungan usaha, meningkatkan pendapatan dan jumlah tamu. Tidak hanya menjaga kualitas makanan, minuman dan pelayanan, namun juga perlu memikirkan faktor-faktor lain yang dapat menunjang usahanya. Penelitian ini bertujuan untuk mengetahui gambaran relationship quality dan word of mouth di restoran de'Leuit yang merupakan salah satu restoran favorit khas sunda di Kota Bogor. Disamping itu juga untuk menganalisis dampak atau pengaruh dari relationship quality tersebut terhadap word of mouth. Penelitian ini dilakukan di bulan Juni-Juli 2018, menggunakan pendekatan kuantitatif dengan teknik analisis regresi linear. Teknik pengumpulan data yang digunakan dalam penelitian ini melalui observasi langsung, penyebaran angket dan studi literatur. Hasil dari analisis menyebutkan bahwa gambaran relationship quality dan word of mouth di restoran De'Leuit Bogor menunjukan skor rata-rata yang termasuk dalam kategori tinggi atau baik, dan relationship quality di restoran De' Leuit Bogor berdampak positip terhadap word of mouth dengan memberikan dampak sebesar $20,1 \%$.

Kata kunci: relationship quality, word of mouth, rekomendasi positif, komunikasi personal

PENDAHULUAN

Dalam perkembangan restoran modern, di samping memperhatikan kualitas makanan, faktor pelayanan juga menjadi sangat penting mengingat semakin ketatnya persaingan usaha, sebagaimana disampaikan Tjiptono (2018) bahwa usaha restoran harus benar-benar mempertimbangkan faktor pelayanannya agar

dapat bersaing dan mendukung kemajuan usaha. Pasar usaha restoran terus berubah dimana tujuan masyarakat makan tidak hanya untuk mencari makanan saja tapi juga di antaranya untuk melarikan diri dari kebosanan, untuk bersosialisasi, untuk memiliki makanan yang berbeda dari yang disajikan di rumah, dan untuk kenyamanan.
\end{abstract} mempunyai keunggulan kompetitif sehingga 
Pertumbuhan industri restoran di Kota Bogor mengalami perkembangan yang cukup pesat sebagaimana dapat dilihat pada tabel 1. Salah satu restoran yang cukup dikenal di Kota Bogor yaitu De'Leuit dirintis sejak tahun (2007). Restoran ini berlokasi di Jl.Pakuan no. 3, Ciheuleut, menyajikan makanan khas Nusantara dan Oriental dengan interior restoran suasana khas Sunda. Menurut Tripadvisor (2018), restoran de'Leuit berada di posisi nomor 2 restoran terbaik di Kota Bogor untuk tahun 2016 dan 2017. Selain itu, Restoran De'Leuit termasuk dalam 7 restoran terlezat di Bogor (http://www.foody.id/2016). Hal tersebut membuat restoran De'Leuit harus berupaya keras untuk dapat terus mempertahankan reputasi makanan dan pelayanannya, namun juga berusaha menarik perhatian dan simpati, menjaga hubungan baik dengan para tamu maupun pelanggan untuk dapat mempertahankan bahkan meningkatkan jumlah tamu. Salah satu strategi pemasaran yang digunakan adalah kekuatan word of mouth. Dengan kekuatan rekomendasi pribadi dari rekan maupun orang terdekat, ternyata dapat meningkatkan kepercayaan konsumen terhadap suatu produk sehingga dengan adanya word of mouth dapat meningkatkan penjualan (Wibowo, 2013).

Tabel 1. Pertumbuhan Industri Kuliner di Kota Bogor

\begin{tabular}{cccc}
\hline Jenis & $\begin{array}{c}\text { Jumlah } \\
(\mathbf{2 0 1 4 )}\end{array}$ & $\begin{array}{c}\text { Jumlah } \\
(\mathbf{2 0 1 5})\end{array}$ & $\begin{array}{c}\text { Jumlah } \\
(\mathbf{2 0 1 6})\end{array}$ \\
\hline Restoran & 145 & 183 & 201 \\
\hline $\begin{array}{c}\text { Rumah } \\
\text { Makan }\end{array}$ & 241 & 257 & 283 \\
\hline $\begin{array}{c}\text { Café dan } \\
\text { Bar }\end{array}$ & 51 & 56 & 62 \\
\hline Katering & 52 & 56 & 60
\end{tabular}

Sumber: Pojok Satu Bogor

Karakter orang Indonesia yang suka berkumpul merupakan cerminan dari kekuatan pembentukan komunitas yang sangat besar pengaruhnya terhadap strategi Word of Mouth. Masyarakat Indonesia yang tingkat interaksinya sangat tinggi dan sebagian besar menggunakan budaya mendengar daripada membaca, komunikasi dari mulut ke mulut lebih efektif untuk mempromosikan produk. Saluran komunikasi personal Word of Mouth tidak menggunakan biaya yang besar karena dengan melalui pelanggan yang puas, rujukan atau referensi terhadap produk hasil produksi perusahaan akan lebih mudah tersebar pada konsumen-konsumen lainnya (Suryani, 2013).

Beberapa peneliti percaya bahwa Relationship Quality adalah indikator serius untuk menganalisis potensi hubungan antara perusahaan dan pelanggan. Relationship Quality merupakan hal penting bagi suatu perusahaan karena dengan adanya Relationship Quality, perusahaan memiliki beberapa keuntungan yaitu untuk membangun dan mempertahankan konsumen yang komit dan yang menguntungkan bagi perusahaan (Rutherford, 2007). Dalam penelitian yang dilakukan oleh Tohidnia \& Haghighi (2011) dalam Esmaeilpour \& Alizadeh (2014), dikemukakan bahwa relationship quality adalah evaluasi dari keseluruhan kekuatan hubungan. Selain itu, relationship quality merupakan alat untuk menelaah masalah dalam membangun dan memelihara hubungan jangka panjang dengan pelanggan, dan syarat untuk retensi pelanggan. Menurutnya, relationship quality dapat diukur dengan tiga dimensi yaitu Trust, Commitment, dan Customer Satisfaction. Menurut Hasan (2013), Trust didefinisikan sebagai persepsi kepercayaan terhadap keandalan perusahaan yang ditentukan oleh konfirmasi sistematis tentang harapan terhadap tawaran perusahaan. Indikator yang digunakan untuk mengukur Trust diantaranya yaitu kepercayaan bahwa restoran memiliki reputasi yang baik selama ini (Utama, 2007) dalam Rakasiwi (2011). Menurut Jahanshahi et al., (2011) Commitment adalah suatu keinginan abadi untuk melanjutkan hubungan dan berperan dalam memperkuat ikatan antara pelanggan dengan suatu produk. Indikator yang digunakan mengacu pada pendapat Morgan dan Hunt (1994) dan Blomer et al. (2002) dan Ramadania (2002) dalam Lita (2009) yaitu memiliki komitmen menjaga hubungannya dengan pelanggan untuk jangka panjang (tidak sematamata mengejar keuntungan), restoran merupakan pilihan pertama untuk dikunjungi dan perasaan bangga menjadi pelanggan restoran. Menurut 
Kotler dan Armstrong (2008) Customer Satisfaction adalah sejauh mana anggapan kinerja produk memenuhi harapan pembeli. Bila kinerja produk lebih rendah ketimbang harapan pelanggan, maka pembelinya merasa puas atau amat gembira. Menurut Zeithaml dan Bitner (2006) definisi Customer Satisfaction adalah respon atau tanggapan konsumen mengenai pemenuhan kebutuhan. Penilaian Customer Satisfaction dapat diukur dengan menggunakan dua atribut yaitu (1). Atrributes related to product atau atribut apa saja baik yang berwujud maupun yang tidak berwujud di dalamnya sudah termasuk pelayanan yang diberikan yang dapat dikonsumsi sehingga dapat memuaskan keinginan dan kebutuhan. Hal tersebut diukur dari jenis produk yang ditawarkan di restoran, rasa makanan dan minuman. (2). Attributes related to service yaitu yang berkaitan dengan pemberian pelayanan pasca pembelian, diukur dari pelayanan yang memuaskan dan sikap ramah serta sopan terhadap konsumen.

Word of mouth merupakan proses komunikasi yang berupa pemberian rekomendasi baik secara individu maupun kelompok terhadap suatu produk atau jasa yang bertujuan untuk memberikan informasi secara personal (Kotler \& Keller, 2006). Di dalam masyarakat, word of mouth dikenal juga dengan istilah komunikasi dari mulut ke mulut. Komunikasi personal ini dipandang sebagai sumber yang lebih dapat dipercaya atau dapat diandalkan. Kotler dan Keller (2006) menyatakan bahwa saluran komunikasi personal dalam ucapan atau perkataan dari mulut ke mulut bisa menjadi metode promosi yang efektif karena pada umumnya disampaikan dari konsumen oleh konsumen dan untuk konsumen, sehingga konsumen yang puas dapat menjadi media iklan bagi perusahaan. Menurut Hasan (2013), konsumen yang percaya pada penyedia jasa atau terlibat dalam proses pembelian cenderung untuk berpatisipasi dalam rekomendasi mulut ke mulut dan pembelaan terhadap penyedia jasa sebagai bagian dari keinginan untuk meningkatkan komitmen mereka. Indikator pengukur word of mouth mengacu pada Wilson (2010), yaitu menceritakan hal-hal positif tentang produk dan jasa, merekomendasikan produk atau jasa kepada orang lain dan mengajak serta membujuk konsumen lain untuk menggunakan produk atau jasa tertentu.

Tujuan penelitian ini adalah: 1). Menganalisis bagaimana gambaran relationship quality dan word of mouth di Restoran de'Leuit Bogor. 2). Menganalisis benarkah Relationship Quality berdampak terhadap word of mouth di Restoran de'Leuit Bogor? 3). Mengetahui berapa besar dampak relationship quality terhadap word of mouth tersebut?

Beberapa penelitian terdahulu menguraikan hubungan dan dampak relationship quality terhadap word of mouth. Menurut Palmatier et al. (2006), dengan dibangunnya relationship quality akan memberikan hasil utama yaitu word of mouth. Mazzarol et al. (2007) menguraikan bahwa kekuatan Relationship Quality antara penyedia layanan dengan pelanggan berdampak pada persepsi potensi Word of Mouth sedangkan Shwu-Ing dan Pei-Chi (2011) dalam Esmaeilpour \& Alizadeh (2014) mengemukakan bahwa dengan relationship quality yang tinggi pelanggan akan merekomendasikan produk melalui word of mouth ke teman-teman atau kerabat. Dari beberapa hasil penelitian tersebut sehingga penentuan hipotesis dalam kajian ini adalah relationship quality memberi dampak terhadap word of mouth.

\section{METODOLOGI PENELITIAN}

Penelitian ini dilakukan di Restoran De'Leuit Bogor, dalam waktu yang sangat terbatas yaitu dalam bulan Juni-Juli 2018. Metode penelitian yang dilakukan menggunakan pendekatan kuantitatif, dengan teknik pengumpulan data melalui kajian literatur, observasi langsung dan melalui angket tertulis (kuesioner). Dalam penelitian ini data primer diperoleh dari hasil kuesioner yang dibagikan kepada pelanggan Restoran De'Leuit. Sedangkan data sekunder diperoleh dari data studi pustaka dan dokumentasi Restoran de'Leuit, jurnal, buku dan sumber lainnya. Penelitian ini menggunakan teknik analisis regresi linera, menggunakan data statistik dari 70 sampel non probability sampling yang diambil secara purposive yaitu penentuan sampel dengan pertimbangan khusus sehingga layak dijadikan sampel. Kriteria atau pertimbangan tertentu dalam menentukan sampel tersebut adalah konsumen yang pernah 
melakukan pembelian/makan di Restoran De"Leuit minimal 2 kali dalam setahun. Teknik pengolahan data dibantu dengan menggunakan SPSS 16.0. Dalam penelitian ini terdapat dua (2) variabel yang diteliti yaitu Relationship Quality sebagai variabel bebas dan Word of Mouth sebagai variabel terikat, sebagaimana dilihat dalam kerangka pemikiran penelitian pada gambar 1.

Gambar 1. Konseptual pemikiran penelitian

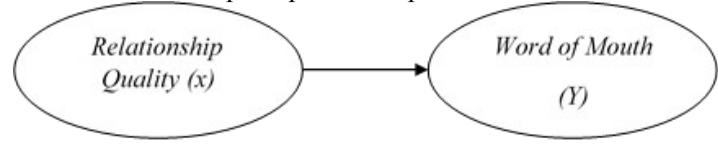

Sumber: data olahan peneliti

Pengukuran relationship quality bedasarkan tiga dimensi yaitu Trust, Commitment, dan Customer Satisfaction. Pengukuran untuk setiap item kuesioner dari masing-masing variabel tersebut diukur berdasarkan pada skala likert dengan lima (5) item scale kriteria sebagai berikut: (1) Sangat tidak setuju (STS) , (2) Tidak setuju (TS), (3) Netral (N), (4) Setuju (S), (5) Sangat setuju (SS).

Tabel 2. Variabel Operasional

\begin{tabular}{|c|c|c|c|}
\hline $\begin{array}{c}\text { Variabel } \\
\text { Dependen } \\
\text { (Y) }\end{array}$ & Dimensi & Indikator & Sumber \\
\hline $\begin{array}{c}\text { Word of } \\
\text { Mouth }(Y)\end{array}$ & $\begin{array}{l}\text { 1) } \\
\text { 2) } \\
\text { 3) }\end{array}$ & $\begin{array}{l}\text { Menceritakan hal- } \\
\text { hal positif tentang } \\
\text { produk/jasa. } \\
\text { Merekomendasikan } \\
\text { produk/jasa kepada } \\
\text { orang lain. } \\
\text { Mengajak dan } \\
\text { membujuk } \\
\text { konsumen lain } \\
\text { untuk menggunakan } \\
\text { produk/jasa tertentu. }\end{array}$ & $\begin{array}{l}\text { Wilson } \\
\text { (2010) }\end{array}$ \\
\hline \multirow[t]{3}{*}{$\begin{array}{c}\text { Variabel } \\
\text { Independen } \\
(\mathrm{X})\end{array}$} & Dimensi & Indikator & Sumber \\
\hline & $\begin{array}{c}\text { Trust } \\
\text { Tohidnia \& } \\
\text { Haghighi } \\
\text { dalam } \\
\text { Ezmaeilpour } \\
\text { \& Alizadeh } \\
\text { (2014) }\end{array}$ & $\begin{array}{l}\text { 1)Kepercayaan } \\
\text { bahwa restoran } \\
\text { memiliki } \\
\text { reputasi yang } \\
\text { baik adalah } \\
\text { reputasi yang } \\
\text { dimiliki oleh } \\
\text { perusahaan } \\
\text { selama ini. }\end{array}$ & $\begin{array}{c}\text { Utama } \\
(2007) \\
\text { dalam } \\
\text { Rakasiwi } \\
(2011)\end{array}$ \\
\hline & $\begin{array}{c}\text { Commitmen } \\
\boldsymbol{t} \\
\text { Tohidnia \& } \\
\text { Haghighi }\end{array}$ & $\begin{array}{l}\text { 1)Restoran } \\
\text { memiliki } \\
\text { komitmen } \\
\text { menjaga }\end{array}$ & $\begin{array}{c}\text { Morgan \& } \\
\text { Hunt } \\
(1994), \\
\text { Bloemer, }\end{array}$ \\
\hline
\end{tabular}

\begin{tabular}{|c|c|c|c|}
\hline \multirow{2}{*}{$\begin{array}{l}\text { Relationship } \\
\text { Quality }(X)\end{array}$} & $\begin{array}{c}\text { dalam } \\
\text { Esmaeilpour } \\
\text { \& Alizadeh } \\
\text { (2014) }\end{array}$ & $\begin{array}{l}\text { hubungannya } \\
\text { dengan } \\
\text { pelanggan } \\
\text { untuk jangka } \\
\text { panjang (tidak } \\
\text { semata-mata } \\
\text { mengejar } \\
\text { keuntungan). } \\
\text { Restoran } \\
\text { merupakan } \\
\text { pilihan } \\
\text { pertama untuk } \\
\text { dikunjungi. } \\
\text { Perasaan bangga } \\
\text { menjadi } \\
\text { pelanggan di } \\
\text { suatu restoran. }\end{array}$ & $\begin{array}{c}(2002) \\
\text { dan } \\
\text { Ramadani } \\
(2002) \\
\text { dalam } \\
\text { Lita } \\
(2009)\end{array}$ \\
\hline & $\begin{array}{c}\text { Customer } \\
\text { Satisfaction } \\
\text { Tohidnia \& } \\
\text { Haghighi } \\
\text { dalam } \\
\text { Ezmaeilpour } \\
\text { \& Alizadeh } \\
(2014: 231)\end{array}$ & $\begin{array}{l}\text { 1)Jenis makanan } \\
\text { dan minuman } \\
\text { yang } \\
\text { ditawarkan } \\
\text { oleh restoran } \\
\text { beragam } \\
\text { 2)Makanan dan } \\
\text { minuman di } \\
\text { restoran } \\
\text { rasanya enak. } \\
\text { 3)Pelayanan yang } \\
\text { memuaskan. } \\
\text { 4)Pihak restoran } \\
\text { ramah dan } \\
\text { sopan terhadap } \\
\text { konsumen. }\end{array}$ & $\begin{array}{c}\text { Dutka, } \\
(2008) \\
\text { dalam } \\
\text { Wijaya \& } \\
\text { Subagio } \\
\text { (2014) }\end{array}$ \\
\hline
\end{tabular}

Sumber : Utama (2007) dalam Rakasiwi (2011), Morgan \& Hunt (1994), Bloemer et al. (2002) dan Ramadani (2002) dalam Wijaya \& Subagio (2014), Wilson (2010), Tohidnia \&Haghighi (2011) dalam Esmaeilpour \& Alizadeh (2014).

Uji instrumen penelitian dan asumsi klasik dilakukan dengan melakukan serangkaian tahapan yaitu Uji validitas menggunakan koefisien korelasi Product Moment, Uji Realiabilitas merujuk kepada koefisien cronbach's. Uji normalitas menggunakan Test of Normality Kolmogorov-Smirnov, uji linieritas menggunakan harga koefisien signifikansi dari Deviatoin from linearity dan dibandingkan dengan nilai alpha yang dipilih yaitu 0,05 dan uji heterokedastitas menggunakan Uji Pearson untuk meregresi nilai absolut residual terhadap variabel independen.

Uji Hipotesis kajian ini dilakukan dengan Uji regresi linear sederhana.

\begin{tabular}{lccc} 
HASIL & \multicolumn{2}{l}{ PENELITIAN } & DAN \\
PEMBAHASAN \\
$\begin{array}{c}\text { Tabel 3. Karakteristik responden } \\
\text { No. }\end{array}$ & Pekerjaan & Responden & $\mathbf{\%}$ \\
\hline 1. & Mahasiswa/I & 23 & $32,9 \%$ \\
\hline & Wiraswasta & 3 & $4,3 \%$ \\
\hline
\end{tabular}




\begin{tabular}{cccc}
\hline & Pegawai negeri & 8 & $11,4 \%$ \\
\hline & Pegawai swasta & 30 & $42,9 \%$ \\
\hline & Lain-lain & 6 & $8,6 \%$ \\
\hline Total & & $\mathbf{7 0}$ & $\mathbf{1 0 0}$ \\
\hline No & Usia & Responden & $\mathbf{\%}$ \\
\hline 1. & $17-25$ Tahun & 14 & $20 \%$ \\
\hline 2. & $26-35$ Tahun & 37 & $52,9 \%$ \\
\hline 3. & $36-45$ Tahun & 13 & $18,6 \%$ \\
\hline 4. & $>45$ Tahun & 6 & $8,6 \%$ \\
\hline Total & & $\mathbf{7 0}$ & $\mathbf{1 0 0}$ \\
\hline No. & Jenis Kelamin & Responden & $\mathbf{\%}$ \\
\hline 1. & Laki-laki & 30 & $42.9 \%$ \\
\hline 2. & Perempuan & 40 & $57.1 \%$ \\
\hline & Total Responden & 70 & $100 \%$ \\
\hline
\end{tabular}

Uji Instrumen Penelitian Dan Asumsi Klasik Data pada tabel 4, didapat hasil dari setiap item pernyataan variabel dari uji validitas adalah valid dengan total keseluruhan $>0,235$. Hasil uji Reliabilitas dapat dilihat pada tabel 4.21 Koefisien Croncbach's Alpha untuk keseluruhan butir intrumen penelitian ini adalah reliable karena memenuhi persyaratan minimal reliabilitas dengan angka $>0,60$.

Tabel 4. Uji Validitas

\begin{tabular}{|c|c|c|c|c|}
\hline No & Pernyataan & rhitung & rtabel & Keterangan \\
\hline \multicolumn{5}{|c|}{ Relationship Quality (X) } \\
\hline 1. & $\begin{array}{l}\text { Restoran de'Leuit } \\
\text { memiliki reputasi } \\
\text { yang baik }\end{array}$ & 0,800 & 0,235 & Valid \\
\hline 2. & $\begin{array}{l}\text { Restoran de'Leuit } \\
\text { memiliki } \\
\text { komitmen } \\
\text { menjaga hubungan } \\
\text { dengan pelanggan }\end{array}$ & 0.800 & 0,235 & Valid \\
\hline 3. & $\begin{array}{l}\text { Restoran de'Leuit } \\
\text { merupakan pilihan } \\
\text { pertama saya } \\
\text { untuk dikunjungi }\end{array}$ & 0.842 & 0,235 & Valid \\
\hline 4. & $\begin{array}{l}\text { Saya bangga } \\
\text { menjadi pelanggan } \\
\text { di Restoran } \\
\text { de'Leuit }\end{array}$ & 0.759 & 0,235 & Valid \\
\hline 5. & $\begin{array}{l}\text { Jenis makanan dan } \\
\text { minuman yang } \\
\text { ditawarkan di } \\
\text { Restoran de'Leuit } \\
\text { beragam }\end{array}$ & 0.708 & 0,235 & Valid \\
\hline 6. & $\begin{array}{l}\text { Makanan dan } \\
\text { minuman Restoran } \\
\text { de'Leuit rasanya } \\
\text { enak }\end{array}$ & 0.742 & 0,235 & Valid \\
\hline 7. & $\begin{array}{l}\text { Pelayanan yang } \\
\text { diberikan } \\
\text { memuaskan }\end{array}$ & 0.727 & 0,235 & Valid \\
\hline 8. & Pihak restoran & 0.789 & 0,235 & Valid \\
\hline
\end{tabular}

\begin{tabular}{|c|c|c|c|c|}
\hline & $\begin{array}{l}\text { ramah dan sopan } \\
\text { terhadap } \\
\text { pelanggan }\end{array}$ & & & \\
\hline No & Pernyataan & 'rhitung & 'tabel & Keterangan \\
\hline \multicolumn{5}{|c|}{ Word of Mouth $(\mathrm{Y})$} \\
\hline 1. & $\begin{array}{l}\text { Saya akan } \\
\text { menceritakan hal- } \\
\text { hal yang positif } \\
\text { mengenai Restoran } \\
\text { de'Leuit }\end{array}$ & 0.846 & 0,235 & Valid \\
\hline 2. & $\begin{array}{l}\text { Saya akan } \\
\text { merekomendasika } \\
\mathrm{n} \text { teman dan } \\
\text { kolega untuk } \\
\text { datang ke Restoran } \\
\text { de'Leuit } \\
\end{array}$ & 0.818 & 0,235 & Valid \\
\hline 3. & $\begin{array}{l}\text { Saya akan } \\
\text { mengajak teman } \\
\text { dan kolega untuk } \\
\text { datang ke Restoran } \\
\text { de'Leuit }\end{array}$ & 0.766 & 0,235 & Valid \\
\hline
\end{tabular}

Tabel 5. Uji Reliabilitas

\begin{tabular}{lll}
\hline Variabel & $\begin{array}{l}\text { Cronbach' } \\
\text { s Alpha }\end{array}$ & Keterangan \\
\hline $\begin{array}{l}\text { Relationshi } \\
\text { p Quality }\end{array}$ & 0,818 & Reliable \\
\hline $\begin{array}{l}\text { Word of } \\
\text { Mouth }\end{array}$ & 0,738 & Reliable \\
Sumber: Olah data SPSS versi 16 &
\end{tabular}

\section{Gambaran Relationship Quality dan Word of Mouth}

Statistik untuk gambaran setiap variabel dalam penelitian ini secara keseluruhan dapat dilihat pada tabel. Penelitian ini menggunakan penilaian skor berdasarkan 5 interval sesuai dengan ketentuan Santosa \& Hamdani (2007), dengan kriteria penilaian adalah sebagai berikut:

$$
\begin{aligned}
& 1,00-1,80=\text { Sangat Rendah } \\
& 1,81-2,61=\text { Rendah } \\
& 2,62-3,42=\text { Sedang } \\
& 3,43-4,43=\text { Tinggi } \\
& 4,44-5,00=\text { Sangat Tinggi }
\end{aligned}
$$

Tabel 6. Statistik Deskriptif

\begin{tabular}{lccccc}
\hline & Total & Min & Max & Mean & $\begin{array}{c}\text { Standar } \\
\text { Deviasi }\end{array}$ \\
\hline $\begin{array}{l}\text { Relationshi } \\
\text { p Quality }\end{array}$ & 70 & 2,50 & 4,63 & 4,06 & 0,43 \\
\hline $\begin{array}{l}\text { Word of } \\
\text { Mouth }\end{array}$ & 70 & 2,33 & 5,00 & 4,05 & 0,43 \\
$\begin{array}{l}\text { Sumber: Olah data SPSS versi 16.0.2016 } \\
\text { Sur }\end{array}$ & & & \\
\hline
\end{tabular}


Berdasarkan data tabel 6 , terlihat bahwa variabel relationship quality memiliki nilai minimum adalah 2,50 dan nilai maksimum 4,63 dan didapat rata-rata jawaban responden adalah 4,06. Dari hasil tersebut dapat diartikan bahwa ratarata jawaban responden atas variabel relationship quality dinilai tinggi. Sedangkan nilai standar deviasi memiliki nilai sebesar 0,43 yang berarti bahwa responden memberikan jawaban yang bervariasi.

Rata-rata (mean) pada variabel word of mouth menunjukkan hasil sebesar 4,05, Dari hasil tersebut dapat diartikan bahwa rata-rata jawaban responden atas variabel word of mouth dinilai tinggi. Nilai minimum untuk variabel word of mouth adalah 2,33 dan nilai maksimum untuk variabel word of mouth 5,00. Sedangkan nilai standar deviasi memiliki nilai sebesar 0,43 yang berarti bahwa responden memberikan jawaban yang bervariasi.

Tabel 7. Analisis Data Deskriptif Sebaran Variabel Relationship Quality

\begin{tabular}{|c|c|c|c|}
\hline No & $\begin{array}{c}\text { Indikator } \\
\text { Tanggapan } \\
\text { Responden } \\
\end{array}$ & Mean & Kriteria \\
\hline 1 & $\begin{array}{ll}\text { Restoran } & \text { de'Leuit } \\
\text { Memiliki } & \text { Reputasi } \\
\text { yang Baik } & \\
\end{array}$ & 4,08 & Tinggi \\
\hline 2 & $\begin{array}{lr}\text { Restoran } & \text { de'Leuit } \\
\text { Memiliki } & \text { Komitmen } \\
\text { Menjaga } & \text { Hubungan } \\
\text { dengan Pelanggan }\end{array}$ & 4,14 & Tinggi \\
\hline 3 & $\begin{array}{lr}\text { Restoran } & \text { de'Leuit } \\
\text { merupakan } & \text { pilihan } \\
\text { pertama } & \text { untuk } \\
\text { dikunjungi } & \\
\end{array}$ & 4,15 & Tinggi \\
\hline 4 & $\begin{array}{l}\text { Saya Bangga menjadi } \\
\text { pelanggan di } \\
\text { Restoran de'Leuit", }\end{array}$ & 4,04 & Tinggi \\
\hline 5 & $\begin{array}{lr}\text { Jenis makanan } & \text { dan } \\
\text { minuman } & \text { yang } \\
\text { ditawarkan } & \text { di } \\
\text { Restoran } & \text { de'Leuit } \\
\text { beragam } & \end{array}$ & 4,18 & Tinggi \\
\hline 6 & $\begin{array}{lr}\text { Makanan } & \text { dan } \\
\text { minuman di Restoran } \\
\text { de'Leuit r rasanya } \\
\text { enak } & \\
\end{array}$ & 4,07 & Tinggi \\
\hline 7 & $\begin{array}{ll}\text { Pelayanan yang } \\
\text { diberikan } \\
\text { memuaskan }\end{array}$ & 4,01 & Tinggi \\
\hline 8 & $\begin{array}{l}\text { Pihak Restoran } \\
\text { ramah dan sopan } \\
\text { terhadap Pelanggan" }\end{array}$ & 4,05 & Tinggi \\
\hline
\end{tabular}

Tabel 8. Analisis Data Deskriptif Sebaran Variabel Word of Mouth

\begin{tabular}{llll}
\hline No & \multicolumn{1}{c}{$\begin{array}{c}\text { Indikator Tanggapan } \\
\text { Responden }\end{array}$} & Mean & Kriteria \\
\hline 1 & $\begin{array}{l}\text { Saya Akan Menceritakan } \\
\text { Hal-hal Positif Mengenai } \\
\text { Restoran de'Leuit }\end{array}$ & & \\
& Tinggi \\
\hline 2 & Saya Akan & 4,12 & Tinggi \\
& Merekomendasikan Teman \\
& dan Kolega untuk Datang ke & & \\
& Restoran de'Leuit & \\
\hline 3 & $\begin{array}{l}\text { Saya Akan Mengajak Teman } \\
\text { dan Kolega untuk Datang ke } \\
\text { Restoran de'Leuit }\end{array}$ & \\
\hline
\end{tabular}

Tabel 9. Uji Linieritas Anova

\begin{tabular}{|c|c|c|c|c|c|}
\hline $\begin{array}{l}\text { Sum of } \\
\text { Squares }\end{array}$ & $\begin{array}{l}\mathrm{Me} \\
\mathrm{Squ}\end{array}$ & & $\mathrm{F}$ & Sig. & \\
\hline (Combined) & 256.506 & 7 & 36.644 & 4.140 & .001 \\
\hline Linearity & 124.512 & 1 & 124.512 & 14.067 & .000 \\
\hline $\begin{array}{l}\text { Deviation } \\
\text { from } \\
\text { Linearity }\end{array}$ & 131.994 & 6 & 21.999 & 2.485 & .032 \\
\hline Within Groups & & & $.765 \quad 62$ & 8.851 & \\
\hline Total & & & $.271 \quad 69$ & & \\
\hline
\end{tabular}

Dari hasil Tabel 9, terlihat bahwa nilai sig lebih besar dari 0,05 yaitu sebesar 0,32, sehingga dapat diartikan terdapat hubungan antara Relationship Quality terhadap Word of Mouth.

Tabel 10. Hasil Analisis Hipotesis

\begin{tabular}{lllc}
\hline Hipotesis & Koefisien B & Signifikansi & Keputusan \\
\hline Relationship & 0,605 & 0,000 & Diterima \\
Quality mempunyai & & & \\
dampak /pengaruh & & & \\
terhadap Word of & & & \\
Mouth & & & \\
Sumber: Olah Data SPSS versi 16.0.2016 & &
\end{tabular}

Variabel relationship quality menghasilkan nilai t statistik sebesar 4.133 dan nilai prob sebesar 0.000. Hal tersebut menunjukkan nilai prob lebih kecil dari alpha sebesar 5\% yang menunjukkan relationship quality berpengaruh terhadap word of mouth. Nilai koefisien sebesar 0.605 menunjukkan nilai yang positif yang berarti semakin baik relationship quality nya maka semakin baik word of mouth nya. 
Tabel 11. Analisis Regresi Linier Sederhana

\begin{tabular}{lccccc}
\hline \multicolumn{5}{c}{ Coefficients $^{\mathbf{a}}$} \\
\hline & $\begin{array}{l}\text { Unstandardize } \\
\text { d Coefficients }\end{array}$ & $\begin{array}{l}\text { Standardized } \\
\text { Coefficients }\end{array}$ & & \\
\cline { 2 - 5 } Model & $\mathrm{B}$ & $\begin{array}{c}\text { Std. } \\
\text { Error }\end{array}$ & Beta & t & Sig. \\
\hline 1(Constant) & 1.596 & .598 & & 2.671 & .009 \\
\hline $\mathrm{X}$ & .605 & .146 & .448 & 4.133 & .000 \\
\hline a. Dependent Variable: $\mathrm{Y}$ & & & \\
\hline
\end{tabular}

Persamaan regresi linier sederhana berdasarkan hasil perhitungan pada tabel 12 adalah :

$$
\mathrm{Y}=1,596+0,605 \mathrm{X}
$$

Tabel 12. Koefisien Determinasi

\begin{tabular}{lll}
\hline $\mathrm{R}$ & $\mathrm{R}$ Square & Std. Error of the Estimate \\
\hline 0,448 & 0,201 & 0,51979 \\
\hline \multicolumn{2}{l}{ Sumber: } \\
\hline
\end{tabular}

Nilai Koefisien deteminan pada tabel $12, \mathrm{R}^{2}$ sebesar 0,201 artinya, dampak atau kontribusi sumbangan variabel Relationship Quality terhadap variabel Word of Mouth sebesar 20,1\%, sedangkan sisanya sebesar $79,9 \%$ dipengaruhi oleh variabel lain yang tidak diteliti.

Tabel 13. Uji T

\begin{tabular}{lll}
\hline Model & $\begin{array}{l}\text { Koefisien } \\
\mathrm{B}\end{array}$ & Signifikansi \\
\hline $\begin{array}{l}\text { Relationshi } \\
\text { p Quality }\end{array}$ & 0,605 & 0,000 \\
Sumber: Olah Data SPSS versi 16.0.2016
\end{tabular}

Berdasarkan signifikansi, nilainya adalah 0,00 atau kurang dari 0,05 , sehingga dapat disimpulkan bahwa Relationship Quality berdampak atau berpengaruh terhadap Word of Mouth.

\section{SIMPULAN}

Berdasarkan hasil kajian maka dapat disimpulkan bahwa gambaran Relationship Quality di Restoran de'Leuit memiliki nilai ratarata 4,0581 sehingga dapat dikatakan tinggi atau baik. Gambaran Word of Mouth di Restoran de'Leuit memiliki nilai rata-rata 4,0523 sehingga dapat dikatakan tinggi atau baik. Nilai signifikansi uji $\mathrm{T}$ kurang dari 0,05 maka Hipotesis dapat diterima atau dapat disimpulkan bahwa Relationship Quality berdampak atau berpengaruh terhadap Word of Mouth, dengan dampak sebesar 20,1\%, sedangkan sisanya
$79,9 \%$ dipengaruhi oleh variabel lain yang tidak diteliti.

\section{DAFTAR PUSTAKA}

Esmaeilpour Majid \& Saadat Alizadeh Maryam. (2014). Surveying the Effect of Relationship Quality on Customer Lifetime Value in Banking System. Pg 226-240.Iran.

Ghozali, Imam. (2011). Aplikasi Analisis Multivarieate Dengan Program SPSS 19 edisi kelima. Semarang: Universitas Dipenogoro.

Hasan, Ali. (2013). Marketing dan Kasus-kasus Pilihan, PT. Buku Seru, Jakarta.

Jahanshahi et al. (2011). Study the Effects of Customer Service and Prodoct Quality on Customer Satisfaction and Loyalty. India: University of Pune. International Journal of Humanities and Social Science Vol.1 No. 7; Spceial Issue June (2011). 253-260.

Kim, Y. K. (2008). Relationship Framework In Sport Management: How Relationship Quality Affects Sport Consumption Behaviors. Dissertation, University of Florida.

Kotler, P. \& Amstrong. (2008). Marketing Management $\left(13^{\text {th }}\right.$ ed.). London: Pearson.

Kotler, P. \& Keller, K.L. (2006). Marketing Management, 12 edition. ed. Prentice Hall. Upper Saddle River. NJ.

Lita, Ratni Prima. (2009). Pengaruh Kepercayaan pada Komitmen Loyalitas Pelanggan. 71-77.

Mazzarol T. . (2007). Conceptualizing Word-ofMouth Activity,Triggers and Conditions: An Exploration Study. European Journal of Marketing, 41:1475-1494.

Mowen, John C \& Minor, Michael. (2008). Consumer Behavior. Edisi Keenam. Prentice-Hall, Inc, New Jersey. 
Mulyadi, (2007). "Efektivitas Word of Mouth", Jurnal Marketing 03/VI/Maret, 53-54.

Palmatier et al. (2006). "Factor Influencing the Effectiveness of Relationship Marketing: A Meta-Analysis." Journal of Marketing 70 (October), 136-53.

Rakasiwi, Eddo. (2011). Pengaruh Kualitas Pelayanan, Kepercayaan dan Kepuasan Terhadap Loyalitas Pelanggan (Studi Pada Bmt Perkasya Semarang).

Rutherford, B., (2007). The Differing Effects of Satisfaction, Trust, and Commitment on Buyer's Behavioral Loyalty: A Study into the Buyer-Salesperson and Buyer-Selling Firm Relationship In a Business-to-Business Context. Marketing Dissertations.

Santoso, Singgih. (2015), Menguasai Statistik Parametrik. Jakarta : PT Elex Media Komputindo.

Suryani, Tatik. (2013). Perilaku Konsumen di Era Imternet : Implikasinya Pada Startegi Pemasaran. Graha Ilmu. http://grahailmu.co.id/index/buku/detil /0/1/3/10/b.

Tohidnia Z, Haghigi M. (2011). "Predictors and outcomes of relationship quality: a guide for customer-oriented strategies", Business Strategy Series, Vol. 12, No. 5, pp. 242-256.

Tjiptono, Fandy. (2008). Strategi Pemasaran, Edisi 3. ANDI: Yogyakarta.

Wibowo, Budi Tri H.S. (2013). Strategi Word of Mouth Telur Asin (Studi Deskriptif Kualitatif Strategi Word of Mouth Penjualan Telur Asin "Nana" di Tawangsari, Sukoharjo.

Zeithaml, V. A., \& Bitner, M. J. (2012). Service marketing (international ed.). New York: McGraw Hill Inc. 